\title{
The territory as an intermediate space
}

\author{
Giovanni Maciocco
}

City, territory, architecture. Three words to supersede a dichotomy: between city and architecture, city and territory, and also architecture and territory. If considered two at a time, these words tend to emphasise their diversity more than their complementarity, as they are also positioned at each end of a range of states of affairs (things). The choice of a title with three words is also a critical reflection as regards antonymous concepts that today have invaded the debate on human settlement. We are thinking, for example, of city and environment or, more in general, nature and artifice. The sequence in which the three words of the title are pronounced is dictated neither by scale nor by a hierarchy, hence the second word, territory, does not follow on but is inserted, as an element common to the others, like a system of relations, an intermediate space, that presses for a reciprocal transformation of the worlds of meaning the three words evoke.

The territory slips into a dual relationship making us reconsider the world of relations inherent in design, in the same way as in The fifth child, by Doris Lessing (1988), there is an intrusion in a family that attests to the impossibility to plan a quiet life and that it is an illusion to think of doing without a relationship with others. This is because everything is always at the border, in the intermediate world between the self and the other, as Silvano Tagliagambe, philosopher and epistemologist of design, argues in this inaugural issue (Tagliagambe 2014). Understood in this way, the concept of intermediate space denotes the symbolic-practical structure around which a society may recognise itself: not just or so much as a border area in the territorial sense as, rather, a terrain of cultural and disciplinary exchange, an attempt to cast off the established mental and cultural systems.

From the territory the city is called upon to rediscover an anchorage to the land, to become aware of its limits of adaptation to unusual situations. And it therefore discovers, not without effort, the reality of our natural condition, and the fact that however immaterial and multiple

\footnotetext{
Correspondence: maciocco@uniss.it

University of Sassari, Architecture at Alghero (AAA), Department of Architecture Planning and Design (DADU), Palazzo del Pou Salit, Piazza
} Duomo 6, 07041 Alghero, Italy the relations are that urban-dwellers enjoy with each other across the planet, they are responsible for the places and a part of the territory. The territory is the space in which the city of places re-emerges in the city of flows, recalling the inseparability of the biological and cultural dimensions in our relationship with the land, the unity between nature and spirit, which Luigi Mazza (2014) refers to in his analysis of the influence of planning on the formation of new concepts of citizenship and common goods. The rediscovery of an anchorage to the land entails a revision of the forms and ways in which this link is interpreted. No longer through the gaze of the strategist who owns the land, but through a gaze pondering over the awareness of reciprocity, respecting its authority (Wenders 1992), which is not a new pantheism, but a critical reflection on the deep meanings that the reciprocity of this relationship has for urban life. This concept is also recalled, for example, by Felix Duque, as a conclusion to his paper on the relationship between public art and urban space construction (Duque 2014). It virtually means that when the city can no longer be designed because urban strategy is more and more entrepreneurial strategy that is hetero-directed by the market, artists take the city by the hand, opening up new urban visions. This is Ernst Bloch's famous Principle of Hope (Bloch 1986) revealing itself, as well as in everyday experience, in art, putting us in touch with the element of mystery and undecidability that permeates the construction of the future, with this "inexpressible" element and the respective utopian tension. The purpose of the Principle of Hope is to try to give sense to our living at a distance from ourselves, thus the utopian ideal par excellence is to rediscover ourselves and rediscover the sense of ourselves in a collective entity, not in the solitary sense.

From the territory architecture is called upon to reflect precisely on the collective sense of man's home, as a search for the primary elements of its construction, a search for what is fundamentally urban, to be rediscovered also in contexts of visual exaltation that tend to "normalise all points of view". It is an approach that tends to discover how our contemporary nature - industrial, mechanical and promotional (Restany 1994) - is changing as concerns the widened environmental sensitivity affecting contemporary

\section{Springer}


life. Various critical studies in the social sciences of the last decades have analysed its influence, exploring, for example, the evolution of environment-based socialisation, as Dino Borri, Domenico Camarda and Rossella Stufano show in the introductory pages to their paper (Borri 2014). The environmental dimension nevertheless find it difficult to be incorporated in the process of disciplinary construction for space design, due to the tension between the moral imperative environmental sustainability has generated and disciplinary construction. The initial results of this interaction are not encouraging, for the moral imperative of sustainable design tends to meet the needs of disciplinary contribution (Mostafavi 2010). A hindrance to the dialectical development - in a truly projectual sense - of this tension between moral imperative of sustainability and disciplinary contribution is represented by the fact that space design continues to be objectoriented, denying the search for process-oriented approaches capable of considering the entirety of the relations between urban development and environmental processes. But it is a necessary dialectical tension since the disciplinary foundations of space design are increasingly required to interact with the problems and perspectives the environmental dimension has opened up in the contemporary spatial condition. A condition that, as Piercarlo Palermo emphasises in his paper (Palermo 2014), cannot have as its prevalent base a notion of landscape limited to settlement environments with a low human impact, but that covers a more radical notion of urban landscape as an interweaving of forms, meanings and experiences of urban life. This is the notion that any urban design, urbanism or urban planning paradigm should tackle nowadays. If understood within this picture, the insertion of the word territory between city and architecture in the title may, by virtue of its otherness, nurture a critical reflection and a radical approach to the vision of the city, in which space design is not simply a form of action taking into account environmental compatibility, but one that will consider the environmental dimension the actual base of a new form of creative imagination and disciplinary innovation.

To consider the territory as intermediate space between city and architecture means to establish an aperture, otherness, a third character, favourable towards mediation and transformation, a character favourable to design understood as a survival strategy that is always experienced in intermediate space, indeed as a terrain of cultural and disciplinary exchange, of eternal negotiation between conflicts, which Arnaldo Cecchini identifies in his paper as essential for city design (Cecchini 2014). If seen in this perspective, intermediate space is also a metaphor for the passage of design from disciplinary soliloquy to multidisciplinary dialogical conception. This means that evolution in the forms and methods of disciplinary construction alone can correspond to the evolution of the city, new spatial events and the change in the urban condition. From these premises it proves clear that the possibilities of reconsidering the discipline of space design require the passage from closed system to open system (Cellucci 1996). We are talking of a radical shift involving the field of requisites of design activity, including, in the first place, the conviction that no disciplinary system is based on intangible, irrevocable principles, so the temporary character of the hypotheses makes each field of knowledge an open system. This favours challenging those hypotheses, such as the cognitive one, that have hindered the opening up of the discipline with tenacious resistance. Design may therefore abandon its own ways of reasoning located in a single selfsufficient system, the one most frequently recurring in the disciplinary tradition of space design, to adopt an alternative method of reasoning, namely shared, multidisciplinary, arising in various kinds of knowledge, and linked by a dialogical relation. In this communicative and dialogical conception of design, the informative base is not pre-established but has to take into account the possibility that new meaning frames arise when different elementary data coming from different kinds of knowledge are linked up. Hence the alternatives are not given a priori and new horizons emerge during the course of the process from an undefined background of possibilities. It is in this spirit that we accept papers for CTA.

Received: 8 April 2014 Accepted: 8 April 2014

Published: 16 May 2014

\section{References}

Bloch E (1986) The principle of hope. MIT Press 3:1938-1947, orig. title Das Prinzio Hoffnung

Borri D, Camarda D, Stufano R (2014) Spatial primitives and knowledge organization in planning and architecture: some experimental notes. City Territory Architecture 1:2

Cecchini A (2014) The future of the city from science to science fiction and back (and beyond). City Territory Architecture 1:5

Cellucci C (1996) L'approccio Logico Alla Pianificazione: Sistemi Chiusi e Sistemi Aperti. In: Maciocco G (ed) La Città in Ombra. Pianificazione urbana e interdisciplinarità, Franco Angeli, Milan

Duque F (2014) Public art and the making of urban space. City Territory Architecture 1:4 Lessing D (1988) The Fifth Child. Jonathan Cape, London

Mazza L (2014) State, citizenship, and common good. British idealists' influence on social philosophy and planning culture. City Territory. Architecture 1:6

Mostafavi M (2010) Why ecological urbanism? Why now?, Wes Jones, big forking dilemma. Contemporary architecture's autonomic turn. Harvard Design Magazine, Spring/Summer 2010:32

Palermo PC (2014) Where are the urban planning and urban design disciplines going? Reflections on the current gap between theory and practice. City Territory Architecture 1:7

Restany P (1994) La Ville Réduite à ses Peaux et Déchets?, Textes Choisis par S. Duplaix, Various Authors, La Ville. Art et Architecture en Europe 1870-1993. Centre Georges Pompidou, Paris

Tagliagambe S (2014) To design is to design oneself. City Territory Architecture 1:8 Wenders W (1992) "The Urban Landscape". W. Wenders, The Act of Seeing, Ubulibri, Milan

doi:10.1186/2195-2701-1-1

Cite this article as: Maciocco: The territory as an intermediate space. City, Territory and Architecture 2014 1:1. 